RESEARCH ARTICLE

\title{
Phylogeographic and phylogenetic analyses of selected set of wild and naturalized Solanum spp. in Sri Lanka
}

\author{
L.T. Ranaweera ${ }^{1, *}$, J. F. Hancock ${ }^{2,3}$, C. K. Weebadde ${ }^{4}$ and S. D. S. S. Sooriyapathirana ${ }^{1}$ \\ ${ }^{1}$ Department of Molecular Biology and Biotechnology, Faculty of Science, University of Peradeniya, Peradeniya, \\ Sri Lanka \\ ${ }^{2}$ Department of Horticulture, Michigan State University, East Lansing, Michigan, USA \\ ${ }^{3}$ Berry Blue LLC, Grand Junction, Michigan, USA \\ ${ }^{4}$ Department of Plant, Soil and Microbial Sciences, Michigan State University, East Lansing, Michigan, USA
}

Received:23/11/2017; Accepted:15/01/2018

\begin{abstract}
Solanum spp. encompass a greater share of the biodiversity in the world. Sri Lanka, one of the biodiversity hotspots in the world, is the home for wide range of Solanum spp. which have been named and morphologically characterized. However, their origins and times of origin have not yet been resolved. Hence, this study was conducted to identify the origins and origination events of 13 wild and naturalized Solanum spp. found in Sri Lanka, using DNA barcoding locus matK in comparison to worldwide Solanum spp. with phylogenetics and divergence dating approaches. In this study, 13 Sri Lankan Solanum spp. were separated into four defined phylogenetic groups viz., Old world, Morelloids, Acanthophora and Trova. The studied Sri Lankan Solanum spp. would have been originated in Africa 2.007 million years ago (MYA) in the Pleistocene epoch through mammalian migration from Mediterranean land bridges. The Australian relatives of Sri Lankan Solanum spp. would have been colonized from South Asia through South East Asia. The floristic connectivity in Pleistocene epoch may have introduced Asian Solanum spp. to South East Asia where mid Miocenic collisions between Australian and Asian plates as well as over water Long Distance Dispersal (LDD) may have caused these species to colonize in Australia. Our analysis demonstrated that most of the Solanum spp. found in Sri Lanka were introduced from India during the Pleistocene ice age. We suggest that Pre Pleistocene migrations of Solanum spp. such as S. nigrum may have occurred through overwater LDD.
\end{abstract}

Keywords: matK, Solanaceae, nightshades, evolution and geodispersal of Solanum, over water Long Distance Dispersal (LDD).

\section{INTRODUCTION}

Solanaceae (nightshades) is one of the most cosmopolitan and economically important families within angiosperms (Samuels, 2009). It contains around 2500 species within 100 genera composed of 14 main clades (Knapp, 1991; Olmstead et al., 2008). Solanaceae contains major vegetable species such as eggplant (Solanum melongena), chili pepper (Capsicum spp.), potato (S. tuberosum) and tomato (S. lycopersicum) and nearly 180 nightshade species are also grown as crops in diverse countries (Samuels, 2015). Solanum is the largest genus in the Solanaceae with 1,250 to 1,750 species distributed in many parts of the world (Frodin, 2004). In general, only $7 \%$ of species in Solanaceae are considered as established crop species although there are many other underutilized Solanaceous species available with edible parts (Samuels, 2015).

Sri Lanka is one of the biodiversity hot spots in the world (Bossuyt et al., 2004) and is home to 15 wild / naturalized and 13 exotic Solanum species (Dassanayake, 1987) and many of them are found in abundance in nearby India. These Solanum species possess valuable economic potential as edible and medicinal plants (Jeyakumar et al., 2016). Different parts of the wild Solanum plants exhibit important medicinal properties including anti-diabetic (Gupta et al., 2005), anticonvulsant (Adesina, 1985), anticancer (Jain et al., 2011), antibacterial (Salar, 2009; Doss et al., 2009), and wound healing properties (Huang et al., 2008) as well as larvicidal activity against mosquitoes (Bansal et al., 2009). Although numerous taxonomic studies have been undertaken, phylogenetic analyses to decipher possible origins and divergence times of the species, bioprospecting programs to characterize important bio-active compounds and biotechnological attempts to utilize these values in economic development are limited for the Solanum species present in Sri Lanka.

History of the geographical distribution of plant species around the world is considered a topic of interest to researchers (Bell et al., 2017; Baldwin and Wagner, 2010; Davis et al., 2002). The Gondwana fragmentation followed by the continental drift is one of the key hypotheses that explains the colonization of the biota in various regions (Yuan et al., 2005; Balme, 1980; Conti et al., 2004; Macey et al., 2000). However, the divergence time for most of the present angiosperms date below 75 million years (Renner, 2004) whereas, Gondwana fragmentation occurred 80 160 million years ago (MYA) (Hall, 1998; Chatterjee and Scotese, 1999). Although fragmentation of Gondwanaland into major continents is considered the first reason for geographic distribution of plants, the wide distribution of plant families such as nightshades can only be addressed through two other hypotheses: land to land distribution through continental connections (Wolfe, 1975; Tiffney, 1985) and over water long distance dispersal (LDD) (Renner, 2004). The formation and breakdown of the central and regional bridges and the occurrence of discrete ice ages might have connected the floristic continuity 
across the countries (Wolfe, 1975; Tiffney, 1985). Over water LDD is also considered as a prime causative agent for higher rates of dispersal events of sessile flora (Baldwin and Wagner, 2010; Booth, 2017; Gillespie et al., 2012; Renner, 2004). Primarily three means of LDD are proposed in Gillespie et al., (2012) namely, wind dispersal, dissemination via oceanic currents or floating rafts and migratory bird mediated distribution. These three mechanisms are considered as regional distribution events and many studies suggest that they were more instrumental in recent floral diversifications events than the effect of Gondwana fragmentation.

The Solanaceae phylogenies, cladistic relationships and the overall evolution are well studied (Knapp, 1991; Weese and Bohs, 2007; Särkinen et al., 2013; Bohs and Olmstead, 1997; Volkov et al., 2001). Species in the genus Solanum consist of many diverse origins such as Eurasian, South American, North American, Asian, Australian and African and moreover, some of these species are endemic to the original geographical ranges (i.e. native ranges). Many studies have used plastid barcoding markers such as matK, $n d h F, \operatorname{trnS}-G$ and trnL-F (Särkinen et al., 2013; Bohs and Olmstead, 1997; Weese and Bohs, 2007), nuclear barcoding markers such as waxy, ITS and $5 s$ rDNA (Särkinen et al., 2013; Volkov et al., 2001) to study these species. However, none of these published studies have considered Solanum spp. in Sri Lanka causing a significant knowledge gap in the phylogenetic grouping, origins and origination events of the species present in the country.

The establishment of phylogroups and origination events of all the Solanaceae species in Sri Lanka is an uphill task, although they would provide a strong platform for germplasm conservation and, cataloging the Sri Lankan species in world wide diversity structures and for application in plant breeding, bio-prospecting and biotech industries studies in order to utilize this wealth of genomic diversity for the economic development. If molecular phylogenetic trees could be established for at least prominent and economically important Solanaceae species, molecular geneticists would enable characterizing the orthologs of the important genes present in the clades and sister-groups. Therefore, the objective of the present study was to establish the molecular phylogenetic relationships, origins and the origination events of a selected group of economically important Solanum spp. in Sri Lanka.

\section{MATERIALS AND METHODS}

\section{DNA sequencing}

The purified DNA isolated from 13 wild and naturalized Solanum spp. in Sri Lanka were PCR amplified using matK primers (forward primer: 5 'CGA TCT ATT CAT TCA ATA TTT C 3' and reverse primer: $5^{\text {ee }}$ TCTAGCACACGAAAGTCGAAGT3 ${ }^{\circ e}$ ) (Jeyakumar et al., 2016), the standard reagents, conditions and primer annealing temperature of $48{ }^{\circ} \mathrm{C}$. The purified PCR products were subjected to Sanger DNA sequencing using ABI 3500 Genetic AnalyzerVersion 4405186. The obtained matK DNA sequences of these 13 species were published in Jeyakumar et al., (2016) in comparison to the morphogenetic diversity structureof the species (Table 1, GenBank Accession Numbers KX258741 to KX258754). The same dataset was used in the present analysis to estimate the origination events of these species.

\section{Phylogenetic analysis}

A set of Basic Local Alignment Search Tool (BLAST) analysis was performed for $13 \mathrm{mat} K$ sequences to fetch all the orthologous Solanum matK sequences available in the GenBank (Table 1). A total of 59 sequences identified through BLAST searches were aligned manually with the sequences of 13 wild and naturalized Solanum species in Sri Lanka using the software MEGA 7 (Kumar et al., 2016). A species from sister group of Solanum clade, Jaltomata bicolor, was used as the out-group to root all the trees in the phylogenetic analysis. The bootstrap+consensus algorithm was executed in Maximum Likelihood framework for 1000 replicates in RAxML-HPC2 Workflow (Stamatakis, 2006) in Cipres Science gateway (Miller et al., 2010). The GTRCAT was used as the nucleotide substitution model to get an accurate and rapid estimation of substitution rate at each site. A Heuristic tree search was initially run in Maximum Parsimony criterion in PAUP V4 (Swofford, 2001) where the strict consensus tree was used as the starting topology in RAxML. The resulting consensus tree was further modified using FigTree v1.4.3 (Rambaut, 2014).

\section{Calibration of divergence time}

The software jModel Test V.2 (Posada, 2008) was initially implemented on Cipres Science gateway (Miller et al., 2010) to measure the best fitting nucleotide substitution model in Akaike information criterion (AIC) (Akaike,1974) for the data set. The software BEAST 2.0 (Drummond and Rambaut, 2007) was used to carry out the divergence time estimation in Bayesian framework. According to the selected model, $\mathrm{TVM}+\mathrm{I}+\mathrm{G}$, the rate $(\mathrm{AC}=1.147$, $\mathrm{AG}=1.057, \mathrm{AT}=-0.216, \mathrm{CG}=0.729, \mathrm{CT}=1.057$ and $\mathrm{GT}=1.0)$ and shape parameters were assigned (Zharkikh, 1994). The uncorrelated log normal clock (Drummond et al., 2006) was used to compensate for the variation of evolutionary rates across the lineages using a lognormal prior with 0.001 mean and 1 standard deviation as well as Birth death model as tree-prior to account for speciation and extinction. A total of eight $S$. dulcamara seed fossils (7.3- 2.6 MYA) from Pliocene epoch (Mai,1988; Reid and Reid, 1907; Szafer, 1946) and a seed fossil $S$. nigrum (5.3 - 11.6 MYA) (van der Beek and van der Burgh, 1987) were used to calibrate two nodes of the time tree developed in the present study. The Time to Most Recent Common Ancestor (TMRCA) for crown of the tree was calibrated using a lognormal prior with 0.001 mean, 0.1 standard deviation and 13.3 MYA offset. The TMRCA was calibrated for root of the tree to be 17 MYA using a lognormal prior. All the node calibration except the fossil data were done as described in Särkinen et al. (2013). The Markov Chain Monte Carlo (MCMC) was performed for 100 million generations with a $10 \%$ burnin to achieve maximum chain convergence. The resulting $\log$ file was analyzed to assess the Effective Sample Size 
Table 1: The matk sequence data used in this study.

\begin{tabular}{|c|c|c|c|}
\hline $\begin{array}{c}\text { Accession } \\
\text { No. }\end{array}$ & Species name & Sequence length & Reference \\
\hline NC_030207* & Solanum melongena & 1521 & NCBI** \\
\hline KX258741 & S. hispidum V. Gonabatu & 936 & Jeyakumar et al., 2016 \\
\hline KX258742 & S. virginianum V. Katuwelbatu & 936 & Jeyakumar et al., 2016 \\
\hline KX258744 & S. nigrum V. Small Kalukenweriya & 936 & Jeyakumar et al., 2016 \\
\hline KX258745 & S. torvum V. Thibbatu & 936 & Jeyakumar et al., 2016 \\
\hline KX258747 & S. melongena $\mathrm{V}$. Large Elabatu & 936 & Jeyakumar et al., 2016 \\
\hline KX258746 & S. trilobatum V. Welthibbatu & 936 & Jeyakumar et al., 2016 \\
\hline KX258749 & S. melongena V. Round Elabatu & 936 & Jeyakumar et al., 2016 \\
\hline KX258748 & S. melongena V. Long Elabatu & 936 & Jeyakumar et al., 2016 \\
\hline KX258750 & S. melongena $\mathrm{V}$. Round Elabatu & 936 & Jeyakumar et al., 2016 \\
\hline KX258751 & S. melongena $\mathrm{V}$. Wambatu & 936 & Jeyakumar et al., 2016 \\
\hline KX258752 & S. melongena $\mathrm{V}$. Wambatu & 936 & Jeyakumar et al., 2016 \\
\hline KX258753 & S. violaceum $\mathrm{V}$. Thithathibbatu & 936 & Jeyakumar et al., 2016 \\
\hline KX258754 & S. pubescens V. Walthibbatu & 936 & Jeyakumar et al., 2016 \\
\hline EU983552 & S. tudununggae & 1530 & Martine et al., 2009 \\
\hline EU983553 & S. dioicum & 1530 & Martine et al., 2009 \\
\hline EU983554 & S. dioicum & 1530 & Martine et al., 2009 \\
\hline EU983555 & S. petraeum & 1530 & Martine et al., 2009 \\
\hline EU983556 & S. carduiforme & 1530 & Martine et al., 2009 \\
\hline EU983557 & S. carduiforme & 1530 & Martine et al., 2009 \\
\hline EU983568 & S. sejunctum & 1530 & Martine et al., 2009 \\
\hline EU983558 & S. carduiforme & 1530 & Martine et al., 2009 \\
\hline EU983559 & S. petraeum & 1530 & Martine et al., 2009 \\
\hline EU983560 & S. leopoldense & 1530 & Martine et al., 2009 \\
\hline EU983561 & S. spLongini & 1530 & Martineet al., 2009 \\
\hline EU983562 & S. chippendalei & 1530 & Martine et al., 2009 \\
\hline EU983563 & S. diversiflorum & 1530 & Martine et al., 2009 \\
\hline EU983564 & S. clarkiae & 1530 & Martine et al., 2009 \\
\hline EU983565 & S. melanospermum & 1530 & Martine et al., 2009 \\
\hline EU983566 & S. oedipus & 1530 & Martine et al., 2009 \\
\hline EU983567 & S. heteropodium & 1530 & Martine et al., 2009 \\
\hline EU983569 & S. sejunctum & 1530 & Martine et al., 2009 \\
\hline EU983570 & S. asymmetriphyllum & 1530 & Martine et al., 2009 \\
\hline EU983572 & S. stupefactum & 1530 & Martine et al., 2009 \\
\hline EU983573 & S. aculeastrum & 1530 & Martine et al., 2009 \\
\hline EU983574 & S. linnaeanum & 1530 & Martine et al., 2009 \\
\hline EU983576 & S. elaeagnifolium & 1530 & Martine et al., 2009 \\
\hline EU983571 & S. hoplopetalum & 1530 & Martine et al., 2009 \\
\hline EU983575 & S. cinereum & 1530 & Martine et al., 2009 \\
\hline AM087200 & S. lycopersicum & 1530 & Kahlau et al., 2006 \\
\hline DQ231562 & S. tuberosum & 1530 & Chung et al., 2006 \\
\hline DQ347958 & S. bulbocastanum & 1530 & Daniell et al., 2006 \\
\hline DQ347959 & S. lycopersicum & 1530 & Daniell et al., 2006 \\
\hline DQ386163 & S. tuberosum & 1530 & Gargano et al., 2005 \\
\hline KM489054 & S. commersonii & 1530 & NCBI \\
\hline JF772170 & S. tuberosum & 1530 & Xuet al., 2011 \\
\hline JF772171 & S. tuberosum & 1530 & Xuet al., 2011 \\
\hline KC535796 & S. clavatum & 1282 & NCBI \\
\hline
\end{tabular}




\begin{tabular}{|c|c|c|c|}
\hline $\begin{array}{c}\text { Accession } \\
\text { No. }\end{array}$ & Species name & Sequence length & Reference \\
\hline KC535797 & S. nigrum & 1282 & $\mathrm{NCBI}$ \\
\hline KC535798 & S. aculeatissimum & 1282 & $\mathrm{NCBI}$ \\
\hline KC535799 & S. sisymbriifolium & 1282 & $\mathrm{NCBI}$ \\
\hline KC535801 & S. aethiopicum & 1281 & NCBI \\
\hline KC535802 & S. torvum & 1282 & $\mathrm{NCBI}$ \\
\hline KT176602 & S. carolinense & 1530 & Aust et al., 2015 \\
\hline KT176603 & S. rostratum & 1530 & Aust et al., 2015 \\
\hline KT176604 & S. triflorum & 1530 & Aust et al., 2015 \\
\hline KY419708 & S. berthaultii & 1530 & $\mathrm{NCBI}$ \\
\hline Z11741 & S. tuberosum & 1530 & $\mathrm{NCBI}$ \\
\hline KU682719 & S. melongena & 1521 & $\mathrm{NCBI}$ \\
\hline KU679363 & S. pyracanthu & 1520 & $\mathrm{NCBI}$ \\
\hline FJ395444 & S. dulcamara & 851 & $\mathrm{NCBI}$ \\
\hline JN894601 & S. dulcamara & 859 & $\mathrm{NCBI}$ \\
\hline FN668838 & S. dulcamara & 846 & $\mathrm{NCBI}$ \\
\hline KP117020 & S. cheesmaniae & 1530 & $\mathrm{Wu}, 2016$ \\
\hline KP117021 & S. chilense & 1530 & $\mathrm{Wu}, 2016$ \\
\hline KP117022 & S. galapagense & 1530 & Wu, 2016 \\
\hline KP117023 & S. habrochaites & 1530 & $\mathrm{Wu}, 2016$ \\
\hline KP117024 & S. lycopersicum & 1530 & Wu, 2016 \\
\hline KP117025 & S. neorickii & 1530 & Wu, 2016 \\
\hline $\begin{array}{l}\text { KP117026 } \\
\text { KP117027 }\end{array}$ & $\begin{array}{l}\text { S. peruvianum } \\
\text { S. pimpinellifolium }\end{array}$ & $\begin{array}{l}1530 \\
1530\end{array}$ & $\begin{array}{l}\text { Wu, } 2016 \\
\text { Wu, } 2016\end{array}$ \\
\hline KP331414 & S. lycopersicum & 1530 & NCBI \\
\hline KР747439 & Jaltomata bicolor & 1530 & Carrizo Garcia et al., 2016 \\
\hline
\end{tabular}

* Reference sequence

**NCBI: Published in National Center for Biotechnology Information

(ESS) and chain convergence in Tracer v1. 4 (Rambaut and Drummond, 2007). The maximum clade credibility (MCC) tree was visualized and further edited in FigTree v1.4.3 (Rambaut, 2014).

\section{RESULTS AND DISCUSSION}

\section{Phylogenetic Analysis}

All the Solanum matK sequences obtained from BLAST searches (E value greater than 98) with Sri Lankan Solanum spp. were included in this analysis (Table 1). The reading frame of matK locus contained 1530 base pairs (bp). The sequences less than $50 \%$ missing bp were excluded from the analysis as Maximum Likelihood (ML) inference can be deluded under the presence of large number of missing data in a non-random passion (Xi et al., 2015). Although some of thesequences included in the analysis contained missing data, both ML majority rule consensus tree and Bayesian Maximum Clade Credibility (MCC) tree branched out similarly at major nodes (Figures 1 and 2). The posterior probability (PP) values and bootstrap (bs) values were higher at these nodes while few nodes towards the tips that were present in the ML collapsed in MCC tree, yielding low PP values even though they had higher bs values.

The initial Maximum Parsimony tree had a well resolved topology given by the Heuristic search. The resolution of the tree was enough to use it as the starting tree topology in RAxML. The ML tree separated the analyzed Solanum species (Table 1) into a total of 10 phylogenetic groups and they were congruent with phylogenetic constructions obtained using different genes in previously published work (Weese and Bohs, 2007; Särkinen et al., 2013; Bohs and Olmstead, 1997). The 13 Sri Lankan Solanum species were separated into four phylogenetic groups namely Old world, Morelloids, Acanthophora and Trova (Olmstead and Bohs, 2006). The robustness of these clusters was displayed by higher node support with PP values larger than $95 \%$ and bs values of 100 (Figure 1). Since our analysis missed some of the phylogenetic groups of Solanum genus, topology at the clade connection was not well resolved. Thus sequences of the other DNA barcoding loci as well as the matK sequences for more Solanum spp. must be incorporated in future studies to identify the robust relationships with higher resolution. However, in the present analysis, major relationships between prominent sister clades remained constant (Särkinen et al., 2013).

\section{Calibration of Divergence Time and Origination \\ Events}

The MCMC chains ran in the tree search converged maximally at $10 \%$ burn-in value. The initial 100,000 trees 


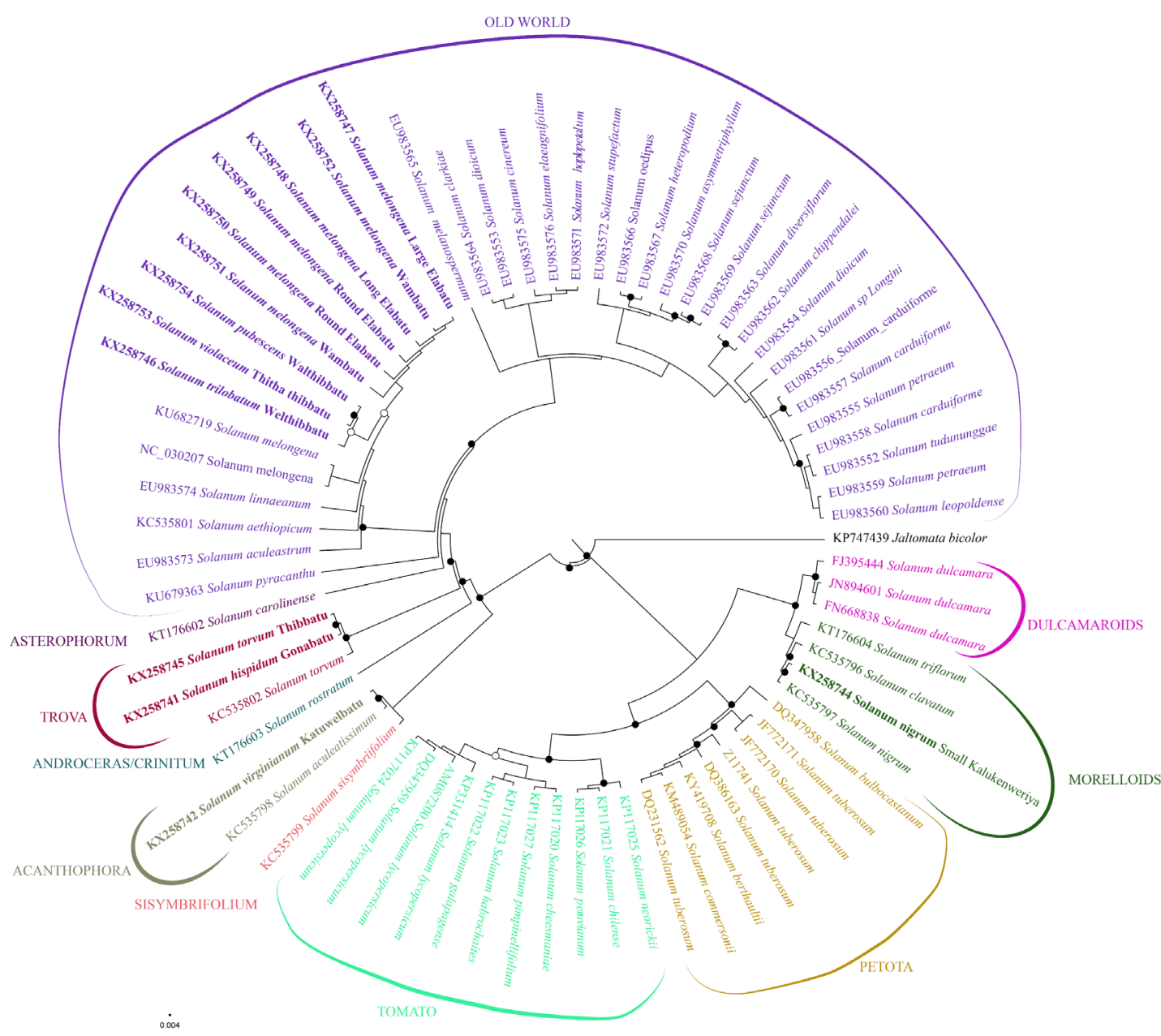

Figure1 : The majority rule consensus tree constructed on Maximum Likelihood (ML) framework. The major phylogenetic groups of Solanum spp. included in this analysis are presented. The node support values are given on its respective nodes indicated either in black dots (over 95 posterior probability and 100 bootstrap value) or white dots (over 85 posterior probability and 95 bootstrap value). The nodes containing posterior probabilities lower than 85 and bootstrap values less than 90 are not shown as dots. The Operational Taxonomic Units of Sri Lankan Solanum spp. are indicated in bold letters.

were discarded as burn-in. The trees were probed from stationary distribution in tree space as all the ESS values calculated were higher than 200, thus inferring our MCMC chains were run long enough (10 million runs) to sample independently and to avoid poor mixing. The divergence time for each node was calibrated according to the TMRCA calibrations.

The three wild Solanum species in Sri Lanka, $S$. pubescens, S. violaceum and S. trilobatum, formed a monophyletic group which was a sister to $S$. melongena group. This group clustered together with $S$. linnaeanum forming a well resolved monophyletic group with clades that are saturated with native Australian Solanum spp. The age of the recent common ancestor of this monophyletic group was calculated as 7.779 MYA [95\% highest posterior density (HPD) at 3.158- 10.236 MYA]. Interestingly Sri Lankan S. hispidum and S. torvum together formed a sister clade with Indian $S$. torvum. The divergence time between these two sister Solanum spp. and their Indian descendent was calculated to be 3.886 MYA (95\% HDP values of $0.148-8.621 \mathrm{MYA})$. The uncorrelated relaxed molecular clock estimated that $S$. nigrum inhabiting in Sri Lanka was descendent from an Indian S. nigrum 5.424 MYA(95\% HPD value of 5.30-5.88 MYA). All S. melongena, S. pubescens
Vern. wal-thibbatu, S. violaceum Vern. thittha thibbatu and S. trilobatum Vern. wel-thibbatu were clustered under the phylogenetic group Old world. This group is closely related to the phylogenetic group Sisymbrifolium sharing a common ancestor 1.556 MYA before in Miocene epoch.

S. virginianum vern. Katuwelbatu which is native to South Asian region (Pandey et al., 2008) was cladded with $S$. aculeatissimum which is known to be a wild Solanum species in India. However, the native range of $S$. aculeatissimum is believed to be from Africa (Hepper and Jaeger, 1986). It is permissible to argue that the mammalian distribution due to late neogenic climatic changes (Cerling et al., 1997) and formation of land connections (Qiu et al., 2001) may have introduced African floral species to Asia. Especially extinct herbivore mammals such as Stegodon were known to have migrated from Africa to Asia 4 MYA (Ao et al., 2016), which might have been a perfect vector for Solanum species to distribute from Afrotropical region to Oriental region. The present analysis confirms that the African $S$. aculeatissimum diverged 2.007 MYA from its Asian sister taxa in Pleistocene epoch which is in parallel to mammalian migration events (Cerling et al., 1997). After introduction of S. aculeatissimum to Oriental region, it might have radiated into Asian region giving rise to $S$. virginianum. The species 


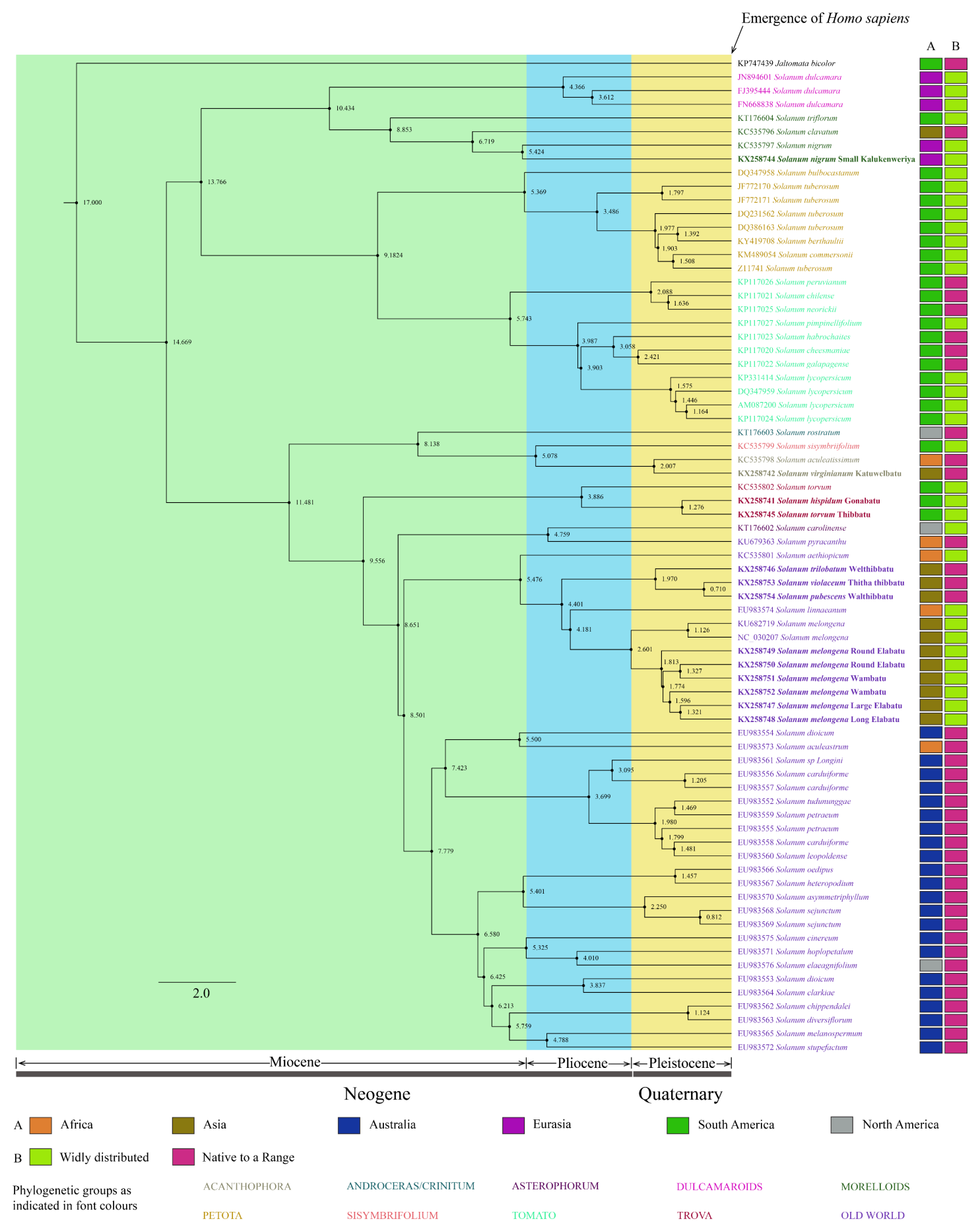

Figure 2 :The Maximum Clade Credibility Tree (MCC) showing the divergence time and geographic distribution of tips (operational taxonomic units). The geological time periods parallel to our divergence dating are given below the tree and tree is colored respectively. The color key below the tree indicates the native range (A) and the current state of distribution (B) of the respective Solanum spp. in the world. The nodes of the tree are labeled with the divergence time (in Million years ago). The Operational Taxonomic Units of Sri Lankan Solanum spp. are indicated in bold letters

S. nigrum Vern. Small Kalukenweriya was cladded with an Indian S. nigrum, however, they got split from each other 5.42 MYA in Miocene epoch. There were frequent sea level fluctuations in Pleistocene epoch (i.e. ice age) to open up gateways to connect Sri Lanka with India (Rohling et al., 1998) however according to the present analysis $S$. nigrum Vern. Small Kalukenweriya would have been introduced to Sri Lanka before Pleistocene ice age probably through over water LDD. The mixing of $S$. nigrum population from India with the Sri Lankan population has not occurred since this was a very early divergent event. Moreover, the phylogenetic group Trova contained three species in the current analysis. Out of these three species, the two Sri Lankan species, S. hispidum Vern. Gonabatu and S. torvum Vern. Thibbatu were found to be sister taxa diverged 2.097 MYA in Pliocene epoch. This group was claded with $S$. 
torvum (KC535802) isolated from India implying that $S$. hispidum and $S$. torvum were split from a common ancestor in India and then colonized to Sri Lanka. S. hispidum would have been evolved from $S$. torvum due to a major speciation event in Pleistocene epoch. It is logical to argue that $S$. hispidum is a more recent species in nightshade family. Similar pattern is shown in Sri Lankan endemic vertebrate and invertebrate species where they share similar morphological traitsal though they keep endemic genetic structures by maintaining unique haplotypes within the island irrespective of numerous chances to mix up due to the frequent formations of land bridges at low sea levels (Bossuyt et al., 2004). It provides insights into the fact that these two $S$. nigrum species evolving into two new species in India and Sri Lanka, but further morphological and molecular phylogenetic analyses are required to resolve their taxonomic status.

It is evident from the present analysis that the diversity of the Sri Lankan Solanum species may also be closely aligned to Australian Solanum spp. All S. melongena, S. pubersena, S. violaceum, S. trilobatum, S. torvum, $S$. hispidum and $S$. virginianum of old world clade (Särkinen et al., 2013; Olmstead et al., 2008) deeply rooted with a clade that is saturated with numerous native Australian Solanum species implying that they would have been distributed across Lydekker's and Wallace's Lines explained in Toussaint et al., (2015). Although as described in "out of India" hypothesis the Gondwana fragmentation has moved many taxa from Africa, through India to South East Asia (Ali et al., 2013), the common ancestor of this Australian-Asian clade dates back to more recent ages. Thus, the only passageway to mix Asian flora with Australian flora is through South East Asia. The Southeast Asian floral diversity is known to originate from east Eurasia and Australia. Large migratory events have been recorded in mid Miocene epoch soon after the Sunda plate collided with Australian plate (Morley, 1998). Plant dispersal LDD by the migrating birds from routes such as East Asian-Australasian Flyway is also possible. Moreover the dispersal routes in late Neogene may have opened up passage ways for animal distribution from South Asia to South East Asia.

\section{CONCLUSION}

The current analyses for the first time describes the phylogenetic positions, origin and origination events of 13 Sri Lankan wild and naturalized Solanum spp. The Solanum diversity in Sri Lanka is strictly connected with the Indian Solanum diversity although the origins of these clades are largely differ from each other.With the molecular dating results we identified two major means of diversification events namely through land bridges of Pleistocene ice age and overwater LDD. Although same species name is given the Solanum species in India and Sri Lanka, the geographical isolation events were dated back to Pleistocene epoc and before, thus a comprehensive systematic and morphological revision is needed to distinguish between Indian and Sri Lankan Solanum spp. The worldwide mixing of Solanaceae germplasm due to continental and regional bridges and migratory birds would have played a significant role in the groups' history. The disturbance to the migratory behavior of birds caused by developmental activities and environmental pollution, habitat fragmentation, global warming may therefore hinder the further reshaping of these germplasm distribution patterns. In the future if these dispersive forces are greatly weakened, the natural evolution of these species would slow down dramatically and get restricted to smaller conservation patches in bio-geographical regions.

\section{REFERENCES}

Adesina, S.K. (1985). Constituents of Solanum dasyphyllum fruit. Journal of Natural Products. 48:147.

Akaike, H. (1974). A new look at the statistical model identification. IEEE transactions on automatic control. 19:716-23.

Ali, S.S., Pfosser, M., Wetschnig, W., Martínez-Azorín, M., Crespo, M.B. and Yu, Y. (2013). Out of Africa: Miocene dispersal, vicariance, and extinction within Hyacinthaceae subfamily Urgineoideae. Journal of Integrative Plant Biology. 55:950-64.

Ao, H., Zhang, P., Dekkers, M.J., Roberts, A.P., An, Z., Li, Y., Lu, F., L, in S and Li, X. (2016). New magnetochronology of Late Miocene mammal fauna, NE Tibetan Plateau, China: Mammal migration and paleoenvironments. Earth and Planetary Science Letters. 434:220-230.

Aust, S.K., Ahrendsen, D.L. and Kellar, P.R. (2015). Biodiversity assessment among two Nebraska prairies: a comparison between traditional and phylogenetic diversity indices. Biodiversity Data Journal. Available from: https://www.ncbi.nlm.nih.gov/pmc/articles/ PMC4549632/(Date of access: 23.11.2017).

Baldwin, B.G. and Wagner, W.L. (2010). Hawaiian angiosperm radiations of North American origin. Annals of Botany. 105: 849-79.

Balme, B.E. (1980). Palynology and the CarboniferousPermian boundary in Australia and other Gondwana continents. Palynology. 4: 43-55.

Bansal, S.K., Singh, K.V and Suresh, K. (2009). Larvicidal activity of the extracts from different parts of the plant Solanumxanthocarpum against important mosquito vectors in the arid region. Journal of Environmental Biology. 30:221-6

Bell, K.L., Rangan, H., Fernandes, M.M., Kull, C.A. and Murphy, D.J. (2017). Chance long-distance or human-mediated dispersal? How Acacia slfarnesiana attained its pan-tropical distribution. Open Science. Available from: http://rsos.royalsocietypublishing.org/ content/4/4/170105?utm_source=TrendMD\&utm_ medium $=$ cpc\&utm_campaign=Royal_Soc_Open_Sci TrendMD_0 (Date of access: 23.11.2017).

Bohs, L. and Olmstead, R.G. (1997). Phylogenetic relationships in Solanum (Solanaceae) based on $n d h F$ sequences. Systematic Botany. 1:5-17.

Booth, T.H. (2017). Going nowhere fast: a review of seed dispersal in eucalypts. Australian Journal of Botany. 65:401-410.

Bossuyt, F., Meegaskumbura, M., Beenaerts, N., Gower, 
D.J., Pethiyagoda, R., Roelants, K., Mannaert, A., Wilkinson, M., Bahir, M.M., Manamendra-Arachchi, K. and Ng, P.K. (2004). Local endemism within the Western Ghats-Sri Lanka biodiversity hotspot. Science. 306:479-81.

Carrizo García, C., Barfuss, M.H., Sehr, E.M., Barboza, G.E., Samuel, R., Moscone, E.A. and Ehrendorfer, F. (2016). Phylogenetic relationships, diversification and expansion of chili peppers (Capsicum, Solanaceae). Annals of Botany. 118:35-51.

Cerling,T.E.,Harris, J.M.,MacFadden,B.J.andLeakey,M.G. (1997) Global vegetation change through the Miocene/ Pliocene boundary. Nature.389(6647):153-158.

Chatterjee, S. and Scotese, C.R. (1999). The breakup of Gondwana and the evolution and biogeography of the Indian plate. Proceedings-Indian National Science Academy Part A. 65:397-426.

Chung, H.J., Jung, J.D., Park, H.W., Kim, J.H., Cha, H.W., Min, S.R., Jeong, W.J. and Liu, J.R. (2006). The complete chloroplast genome sequences of Solanum tuberosum and comparative analysis with Solanaceae species identified the presence of a 241-bp deletion in cultivated potato chloroplast DNA sequence. Plant Cell Reports. 25:1369-1379.

Conti, E., Rutschmann, F., Eriksson, T., Sytsma, K.J. and Baum, D.A. (2004). Calibration of molecular clocks and the biogeographic history of Crypteroniaceae: a reply to Moyle. Evolution. 58:1874-1876.

Daniell, H., Lee, S.B., Grevich, J., Saski, C., QuesadaVargas, T., Guda, C., Tomkins, J. and Jansen, R.K. (2006). Complete chloroplast genome sequences of Solanum bulbocastanum, Solanum lycopersicum and comparative analyses with other Solanaceae genomes. Theoretical and Applied Genetics. 112(8):1503-18.

Davis, C.C., Bell, C.D., Mathews, S. and Donoghue, M.J. (2002). Laurasian migration explains Gondwanan disjunctions: evidence from Malpighiaceae. Proceedings of National Academy of Science. 99:68336837.

Dassanayake, M.D. (1987). A Revised Handbook to the Flora of Ceylon (volvi). New Delhi: Amerind Publishing Co Pvt Ltd.

Doss, A., Mubarack, H.M. and Dhanabalan, R. (2009). Antibacterial activity of tannins from the leaves of Solanum trilobatum Linn. Indian Journal of Science and Technology. 2:41-43.

Drummond, A.J. and Rambaut, A. (2007). BEAST: Bayesian evolutionary analysis by sampling trees. BMC Evolutionary Biology. 7:214.

Drummond, A.J., Ho, S.Y., Phillips, M.J. and Rambaut, A. (2006). Relaxed phylogenetics and dating with confidence. PLOS Biology. 4(5):e88.

Frodin, D.G. (2004). History and concepts of big plant genera. Taxon. 53:753-776.

Gargano, D., Vezzi, A., Scotti, N., Gray, J.C., Valle, G., Grillo, S. and Cardi, T. (2005). The complete nucleotide sequence genome of potato (Solanum tuberosumcv Désirée) chloroplast DNA. Book of Abstracts of the 2nd Solanaceae Genome Workshop, Pp. 107.

Gillespie, R.G., Baldwin, B.G., Waters, J.M., Fraser, C.I., Nikula, R. and Roderick, G.K. (2012). Long-distance dispersal: a framework for hypothesis testing. Trends in Ecology and Evolution. 27(1):47-56.

Gupta, S., Mal, M., Bhattacharya, P. (2005) Evaluation of hyperglycemia potential of $S$. xanthocarpum fruit in normal and streptozin induced diabetic rats. European Bulletin Drug Research. 13:51-55.

Hall, R. (1998) The plate tectonics of Cenozoic SE Asia and the distribution of land and sea. Biogeography and geological evolution of SE Asia. 99-131.

Hepper, F., Jaeger, P .(1986) A review of the genus Solanum in Africa. Solanaceae Biology and Systematics Columbia University Press New York, USA 41-55.

Huang, W.H., Hsu, C.W. and Fang, J.T. (2008). Central diabetes insipidus following digestion Solanum indicum L. concentrated solution. Clinical Toxicology. 46:293-296.

Jain, R., Sharma, A., Gupta, S., Sarethy, I.P. and Gabrani, R. (2011) Solanum nigrum: current perspectives on therapeutic properties. Alternative Medicine Review 16:78-85.

Jeyakumar, D., De Silva, U., Dissanayake, R., Chamikara, M. and Sooriyapathirana, S. (2016). Morpho-genetic diversity and anti-bacterial activity in root extracts of nine solanaceous species. Tropical Agricultural Research. 28:64-87.

Kahlau, S., Aspinall, S., Gray, J.C. and Bock, R. (2006). Sequence of the tomato chloroplast DNA and evolutionary comparison of solanaceous plastid genomes. Journal of Molecular Evolution. 63:194-207.

Knapp, S. (1991). A cladistic analysis of the Solanum sessile species group (section Geminata pro parte: Solanaceae). Botanical Journal of the Linnean Society. 106:73-89.

Kumar, S., Stecher, G. and Tamura, K. (2016). MEGA7: Molecular Evolutionary Genetics Analysis version 7.0 for bigger datasets. Molecular Biology and Evolution. 33:1870-1874.

Macey, J.R., Schulte, J.A., Larson, A., Ananjeva, N.B., Wang, Y., Pethiyagoda, R., Rastegar-Pouyani, N. and Papenfuss, T.J. (2000). Evaluating transTethys migration: an example using acrodont lizard phylogenetics. Systematic Biology. 49(2):233-56.

Mai, D.H. (1988). Die pliozänen Floren von Thüringen, Deutsche Demokratische Republik. Akademie-Verlag.

Martine, C.T., Anderson, G.J. and Les, D.H. (2009). Gender-bending aubergines: Molecular phylogenetics of cryptically dioecious Solanum in Australia. Australian Systematic Botany. 22:107-120.

Miller, M.A., Pfeiffer, W. and Schwartz, T. (2010). Creating the CIPRES Science Gateway for inference of large phylogenetic trees. Gateway Computing Environments Workshop (GCE). Pp 1-8.

Morley, R.J. (1998). Palynological evidence for Tertiary plant dispersals in the SE Asian region in relation to plate tectonics and climate. Biogeography and geological evolution of SE Asia. 211-234.

Olmstead, R.G. and Bohs, L.A. (2006). Summary of molecular systematic research in Solanaceae: 19822006. Proceedings of VI International Solanaceae Conference: Genomics Meets Biodiversity. 745:255268. 
Olmstead, R.G., Bohs, L., Migid, H.A., Santiago-Valentin, E., Garcia, V.F. and Collier, S.M. (2008). A molecular phylogeny of the Solanaceae. Taxon. 57:1159-1181.

Pandey, A., Tomer, A.K., Bhandari, D. and Pareek, S. (2008). Towards collection of wild relatives of crop plants in India. Genetic Resources and Crop Evolution. 55:187-202.

Posada, D. (2008). jModelTest: phylogenetic model averaging. Molecular Biology and Evolution. 25:12531256.

Qiu, Z.X., Wang, B.Y., Qiu, Z.D., Heller, F., Yue, L.P., Xie, G.P., Wang, X.M. and Engesser, B. (2001). Land mammal geochronology and magnetostratigraphy of mid-Tertiary deposits in the Lanzhou Basin, Gansu Province, China. 94:373-385.

Rambaut, A. (2014) FigTree, a graphical viewer of phylogenetic trees. Available from: http://tree. bio. ed. ac. uk/software/figtree. (Date of access: 20.08.2017).

Rambaut, A. and Drummond, A. (2007) Tracer v1. 4. Available from : http://beast. bio. ed. ac. uk/Tracer. (Date of access: 15.08.2017).

Reid, C. and Reid, E.M. (1907). Fossil flora of Tegelen-surMeuse, near Venloo, in the Province of Limburg.

Renner, S. (2004). Plant dispersal across the tropical Atlantic by wind and sea currents. International Journal of Plant Science. 165:S23-S33.

Rohling, E., Fenton, M., Jorissen, F. and Bertrand, P. (1998). Magnitudes of sea-level lowstands of the past 500,000 years. Nature. 394:162-165.

Salar, R.K. (2009). Evaluation of antimicrobial potential of different extracts of Solanum xanthocarpum Schrad. andWendl. African Journal of Microbiology Research. 3:97-100.

Samuels J. (2009). The Solanaceae-novel crops with high potential. Organic Grower. 9:32-34

Samuels, J. (2015). Biodiversity of food species of the Solanaceae family: a preliminary taxonomic inventory of subfamily Solanoideae. Resources. 4:277-322.

Särkinen, T., Bohs, L., Olmstead, R.G. and Knapp, S. (2013). A phylogenetic framework for evolutionary study of the nightshades (Solanaceae): a dated 1000-tip tree. BMC Evolutionary Biology. 13:214-229.

Stamatakis, A. (2006). RAxML-VI-HPC: maximum likelihood-based phylogenetic analyses with thousands of taxa and mixed models. Bioinformatics. 22:2688-2690.

Swofford, D.L. (2001). Paup*: Phylogenetic analysis using parsimony (and other methods) 4.0. B5.

Szafer, W. (1946). Flora plioceńska z Krościenka n/ Dunajcem. Polska Akademija Umiejętności.

Tiffney, B.H. (1985). Perspectives on the origin of the floristic similarity between eastern Asia and eastern North America. Journal of Arnold Arborentum. 66:7394.

Toussaint, E.F., Tänzler, R., Rahmadi, C., Balke, M. and Riedel, A. (2015) Biogeography of Australasian flightless weevils (Curculionidae, Celeuthetini) suggests permeability of Lydekker's and Wallace's Lines. Zoologica Scripta. 44:632-644

van der Beek, C.G.A. and van der Burgh, A.H.P. (1987). On the periodic wind-induced vibrations of an oscillator with two degrees of freedom. Nieuw Archiefvoor
Wiskunde. 2:207-225.

Volkov, R.A., Zanke, C., Panchuk, I.I. and Hemleben, V. (2001). Molecular evolution of 5S rDNA of Solanum species (sect. Petota): application for molecular phylogeny and breeding. TAG. 103:1273-1282.

Weese, T.L. and Bohs, L. (2007). A three-gene phylogeny of the genus Solanum (Solanaceae). Systematic Botany. 32:445-463.

Wolfe, J.A. (1975). Some aspects of plant geography of the Northern Hemisphere during the late Cretaceous and Tertiary. Annals of Missouri Botanical Garden. 62:264-279.

$\mathrm{Wu}, \mathrm{Z}$. (2016). The completed eight chloroplast genomes of tomato from Solanum genus. Mitochondr DNA Part A. 27:4155-4157.

Xi, Z., Liu, L. and Davis, C.C. (2015). The impact of missing data on species tree estimation. Molecular Biology and Evolution. 33:838-860.

Xu, X., Pan, S., Cheng, S., Zhang, B., Mu, D., Ni, P., Zhang, G., Yang, S., Li, R., Wang, J. and Orjeda, G. (2011). Genome sequence and analysis of the tuber crop potato. Nature. 475:189-195.

Yuan, Y.M., Wohlhauser, S., Möller, M., Klackenberg, J., Callmander MW and Küpfer P. (2005). Phylogeny and biogeography of Exacum (Gentianaceae): a disjunctive distribution in the Indian Ocean Basin resulted from long distance dispersal and extensive radiation. Systematic Biology. 54:21-34.

Zharkikh, A. (1994). Estimation of evolutionary distances between nucleotide sequences. Journal of Molecular Evolution. 39:315-329. 